\title{
THE DOSE RECEIVED BY PATIENTS DURING DENTAL X-RAY EXAMINATION AND THE TECHNICAL CONDITION OF RADIOLOGICAL EQUIPMENT
}

\author{
OCENA DAWKI PROMIENIOWANIA X U OSÓB PODDAWANYCH RENTGENOWSKIM BADANIOM STOMATOLOGICZNYM \\ ORAZ STANU TECHNICZNEGO STOSOWANEGO SPRZĘTU
}

\author{
National Institute of Public Health - National Institute of Hygiene / Narodowy Instytut Zdrowia Publicznego - \\ Państwowy Zakład Higieny, Warszawa, Poland \\ Department of Radiation Hygiene and Radiobiology / Zakład Higieny Radiacyjnej i Radiobiologii
}

\begin{abstract}
Background: Implementation of X-ray dental examination is associated with the patient's exposure to ionizing radiation. The size of the exposure depends on the type of medical procedure, the technical condition of the X-ray unit and selected exposure conditions. The aim of this study was to determine the dose received by patients during dental X-ray examination and the assessment of the technical condition of medical equipment. Materials and Methods: The study included a total number of 79 dental $\mathrm{X}$-ray units located in the region of Mazovia. The test methods for the assessment of the technical condition of dental X-ray units and measurement of radiation dose received by patients were based on the procedures elaborated in the Department of Radiation Hygiene and Radiobiology in the National Institute of Public Health - National Institute of Hygiene (Warszawa, Poland) accredited for the certification of compliance with PN-EN 17025. Results: The research found that $69.6 \%$ fully meets the criteria set out in the Polish legislation regarding the safe use of ionizing radiation in medicine, while $30.4 \%$ did not meet some of them. A tenfold difference in the size of the dose received by patients during dental X-ray examinations was discovered. For example, during a radiography of the canine teeth of a child, the recorded entrance surface dose (ESD) ranged from 72.8 to $2430 \mu \mathrm{Gy}$ with the average value of $689.1 \mu \mathrm{Gy}$. Cases where the dose reference level defined in Polish legislation of $5 \mathrm{mGy}$ was exceeded were also found. Conclusions: It is essential to constantly monitor the situation regarding the technical condition of X-ray units which affects the size of the population's exposure to ionizing radiation as well as raising dentists' awareness about the effects of X-rays on the human body. Med Pr 2013;64(6):755-759
\end{abstract}

Key words: dental radiology, ESD, X-ray medical diagnostic procedures

\begin{abstract}
STRESZCZENIE
Wprowadzenie: Wykonywanie rentgenowskich badań stomatologicznych wiąże się z narażeniem pacjenta na działanie promieniowania jonizującego. Wielkość tego narażenia zależna jest od wykonywanej procedury medycznej, stanu technicznego aparatu rentgenowskiego oraz dobranych warunków ekspozycji. Celem niniejszych badań było określenie wielkości dawek, na jakie narażeni są pacjenci podczas rentgenowskich badan stomatologicznych, oraz ocena stanu technicznego używanej do tego celu aparatury medycznej. Materiał i metody: Badaniami objęto łącznie 79 stomatologicznych aparatów rentgenowskich, zlokalizowanych na terenie województwa mazowieckiego. Metodyka badań dotycząca oceny stanu technicznego tych urządzeń oraz pomiaru dawek otrzymywanych przez pacjentów oparta została na opracowanych w Zakładzie Higieny Radiacyjnej i Radiobiologii Narodowego Instytutu Zdrowia Publicznego - Państwowego Zakładu Higieny w Warszawie procedurach badawczych, akredytowanych w jednostce certyfikującej na zgodność z normą PN-EN 17025. Wyniki: W wyniku przeprowadzonych badań stwierdzono, że 69,6\% aparatów w pełni spełnia kryteria określone w ustawodawstwie polskim dotyczącym bezpiecznego stosowania promieniowania jonizującego w medycynie, a 30,4\% nie spełnia części z nich. Zaobserwowano kilkudziesięciokrotne różnice w wielkości dawek, jakie otrzymują pacjenci w trakcie stomatologicznych badań rentgenowskich. Przykładowo w trakcie radiografii zęba kła u dziecka wartości rejestrowanej wejściowej dawki powierzchniowej (entrance surface dose - ESD) mieszczą się w przedziale 72,8-2430 $\mu$ Gy przy wartości średniej $689,1 \mu \mathrm{Gy}$. Stwierdzono także przypadki przekroczenia wartości dawki referencyjnej określonej w polskim ustawodawstwie, która wynosi 5 mGy. Wnioski: Niezbędne jest stałe monitorowanie stanu technicznego aparatów rentgenowskich, który ma wpływ na wielkość narażenia populacji na promieniowanie jonizujące. Konieczne jest też podnoszenie świadomości lekarzy stomatologów w zakresie skutków oddziaływania promieniowania rentgenowskiego na organizm człowieka. Med. Pr. 2013;64(6):755-759
\end{abstract}

Słowa kluczowe: radiologia stomatologiczna, ESD, radiologiczne procedury medyczne

Corresponding author / Autor do korespondencji: Marcin Bekas, Department of Radiation Hygiene and Radiobiology, National Institute of Public Health - National Institute of Hygiene, Chocimska 24, 00-791 Warszawa, Poland, e-mail: mbekas@pzh.gov.pl Received: 2013, October 8, accepted: 2013, December 2

The study has been financed by the National Center of Science as research project No N 404109339 "Radiation risk from X-ray diagnostic procedures and cancer risk in the Masovian Province”. Manager of the project: Marcin Bekas, PhD. 


\section{INTRODUCTION}

Setting a medical diagnose requires conducting patient examination. One of them is X-Ray diagnostics, that allows to depict the inside structures of the patient body. The method and quality of test performance have a significant impact on further treatment of the sick person and, thus, the prognosis as to their recovery. X-ray examinations are commonly performed in almost all countries of the world. The advantage of this examination (e.g. in traffic accidents) is its easy execution, very fast result and low cost of the test itself. To carry out such investigations, it is necessary to choose the suitable exposure conditions depending on the medical procedure, the patient's physique and the method of registering X-ray image (1-3).

The implementation of X-ray examination, regardless of the type, is associated with the patient's exposure to ionizing radiation. X-ray tomography and procedures related to interventional radiology are the most influencing examinations, while dental X-rays are the least (4). It is worth mentioning that diagnostic $\mathrm{X}$-rays carry the risk of inducing additional cancers. It is estimated that, each year, tens to thousands of patients in countries where radiography is performed suffer from cancer of different organs (5). The aim of this study was to determine the dose received by patients during dental X-ray examinations and the assessment of the technical condition of medical equipment.

\section{MATERIALS AND METHODS}

Prior to the study, it was necessary to determine the number of X-ray dental units used in the Masovian Province. For this purpose, the reporting form GUS MZ-52 was used, drawn up annually by province state sanitary-epidemiological stations. It was found that, in the region of Mazovia, 1435 intraoral dental $\mathrm{X}$-ray units were used. Subsequently, there was a random selection of medical centers where measurements of the technical condition of the X-ray units were performed along with the measurements of entrance surface doses (ESD) received by patients during examinations.

The measurements were done in accordance with internal procedures elaborated in the Radiation Protection and Radiobiology Department. The procedures were accredited in the Polish Centre for Accreditation in Warsaw - Certificate No AB-509. The scope of research was carried out in accordance with the regulation applicable in this regard, the Ministry of Health (2).
The procedure included the control of proper operation of the high voltage generator, consistency and repeatability of the exposure time, thickness of the half value layer, X-Ray tube output, the size of the total filtration of the beam, the distance between the X-ray focus and the patient's skin and the focal spot size (6). Each of these parameters was subject to separate assessment and the results indicated that the measured values did not exceed the tolerance limits specified in Annex No. 6 to the said Regulation (2). The Radiation Protection and Radiobiology Department had been working on the quality control of X-ray units for several years (7-11).

The sample size selected for the study was tested for some representativeness of the whole region (12). It was found that, with probability of 0.95 , we can assume that the data collected from 49 dental X-ray units is sufficient to assess their technical condition in the Masovian Province.

The entrance surface dose (ESD) received by patients during routine testing was also measured. For this purpose, the PTW Diados E dosemeter was used. The detector was placed on a phantom simulating the patient's head. The phantom was made of PMMA (polymethyl methacrylate) with a diameter of $16 \mathrm{~cm}$. In each X-ray room, in accordance with the dentist and the medical documentation kept for individual patients, the examination conditions for adults and children were recorded for four medical dental procedures (eye-tooth, foretooth, premolar, molar). Each time the exposure conditions $(\mathrm{kV}, \mathrm{mAs})$ selected by the dentist were recorded for each procedure and, subsequently, X-ray examinations were performed. The ESD was recorded with the dosemeter placed on the PMMA phantom.

\section{RESULTS}

The study included 79 dental X-ray units out of a total number of 1435 units used in the Masovian Province, which is $5.51 \%$. It was found that $69.6 \%$ of the tested $\mathrm{X}$-ray units fully meet the criteria set out in the Polish legislation, while $30.4 \%$ did not meet some of them. For the X-ray units that do not meet the criteria, the most common issue was their inaccurate exposure time $(53 \%)$, X-ray output (16\%), high voltage inaccuracy (13\%), too small thickness of the half value layer with a minimum value of $1.8 \mathrm{~mm} \mathrm{Al}$ for $60 \mathrm{kV}$ and $2.1 \mathrm{~mm} \mathrm{Al}$ for $70 \mathrm{kV}(9 \%)$ and the focal spot size $(9 \%)$. For some units, more than one technical issues were found (10.1\%). The results of the most ascertained abnormalities are presented in Figure 1. 


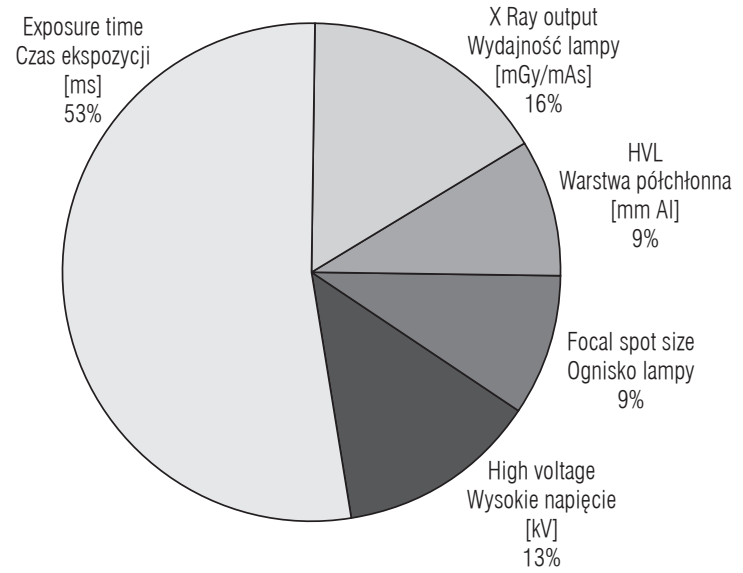

Fig. 1. Percentage distribution of negatively evaluated technical parameters of dental X-ray units

Ryc. 1. Rozkład procentowy negatywnie ocenionych parametrów technicznych stomatologicznych punktowych aparatów rtg.

When evaluating the entrance surface doses (ESD) received by adults and children, the conditions selected by the dentist were recorded for the four most commonly used medical procedures (Table 1). $474 \mathrm{X}$-ray exposure conditions were collected, including the selected $\mathrm{kV}$ and $\mathrm{mAs}$ value (237 exposure conditions for each group: adults and children).

The average value of the high voltage for pediatric dental radiography is $64.8 \mathrm{kV}$, and for adult patients, de- pending on the tested tooth, the range is $65.6-66.5 \mathrm{kV}$. The $\mathrm{mAs}$ value does not exceed $4.1 \mathrm{mAs}$ (molar radiography) for children and $10 \mathrm{mAs}$ (molar radiography) for adult patients. The sizes of the entrance surface doses (ESD) received by patients during dental examinations are presented in Table 2. ESD doses were measured on a PMMA phantom, using the exposure conditions of 474 patients ( 273 adults, 273 children).

A difference of 10 was discovered on the dose received by patients during dental X-ray examinations. For example, during a radiography of the canine teeth of a child, an ESD dose ranged from $72.8 \mu \mathrm{Gy}$ to $2430 \mu \mathrm{Gy}$ was recorded with an average value of $689.1 \mu \mathrm{Gy}$. However, the greatest range of measured ESD doses was found during molar radiography of adult patients. The range was from $159.5 \mu \mathrm{Gy}$ to $6113.0 \mu \mathrm{Gy}$, with an average value of $1520.3 \mu \mathrm{Gy}$. It is worth mentioning that the highest ESD measured was 4 times higher than the calculated average value of all of the performed procedures.

\section{DISCUSSION}

The results indicate that the condition of dental X-ray units is not satisfactory because $30.4 \%$ of them do not fully meet the criteria set out in the Polish legislation (2). Analyzing the various parameters of X-ray units, it should be noted that they not only have an

Table 1. The exposure parameters used in dental medical procedures

Tabela 1. Parametry ekspozycji stosowane przy stomatologicznych procedurach medycznych

\begin{tabular}{|c|c|c|c|c|c|c|c|c|c|c|c|c|}
\hline \multirow{3}{*}{$\begin{array}{c}\text { Examination } \\
\text { Procedura medyczna }\end{array}$} & \multicolumn{12}{|c|}{$\begin{array}{l}\text { Parameters } \\
\text { Parametry }\end{array}$} \\
\hline & \multicolumn{6}{|c|}{$\begin{array}{l}\text { child } \\
\text { dziecko }\end{array}$} & \multicolumn{6}{|c|}{$\begin{array}{l}\text { adult } \\
\text { dorosły }\end{array}$} \\
\hline & \multicolumn{3}{|c|}{$\begin{array}{c}\text { high voltage } \\
\text { wysokie napięcie } \\
{[\mathrm{kV}]}\end{array}$} & \multicolumn{3}{|c|}{$\begin{array}{c}\mathrm{I} \times \mathrm{t} \\
{[\mathrm{mAs}]}\end{array}$} & \multicolumn{3}{|c|}{$\begin{array}{c}\text { high voltage } \\
\text { wysokie napięcie } \\
{[\mathrm{kV}]}\end{array}$} & \multicolumn{3}{|c|}{$\begin{array}{c}\mathrm{I} \times \mathrm{t} \\
{[\mathrm{mAs}]}\end{array}$} \\
\hline $\begin{array}{l}\text { Dental radiographs: eye-tooth / Radiografia } \\
\text { zęba: kieł }\end{array}$ & $60-70$ & 64.8 & 4.9 & $0.1-3.2$ & 1.1 & 0.9 & $60-70$ & 66.4 & 3.8 & $0.3-8.0$ & 1.8 & 1.7 \\
\hline $\begin{array}{l}\text { Dental radiographs: fore-tooth / Radiografia } \\
\text { zęba: siekacz }\end{array}$ & $60-70$ & 64.8 & 4.9 & $0.2-3.3$ & 0.9 & 0.8 & $60-70$ & 65.6 & 4.7 & $0.3-8.0$ & 1.6 & 1.6 \\
\hline $\begin{array}{l}\text { Dental radiographs: premolar / } \\
\text { / Radiografia zęba: ząb przedtrzonowy }\end{array}$ & $60-70$ & 64.8 & 4.9 & $0.2-4.1$ & 1.3 & 1.1 & - & - & - & - & - & - \\
\hline
\end{tabular}

I - natężenie prądu elektrycznego / electric current; $\mathrm{t}$ - czas / time.

$\mathrm{R}$ - range / zakres.

$\mathrm{M}$ - mean / wartość średnia.

SD - standard deviation / odchylenie standardowe. 
Table 2. Entrance surface dose (ESD) received by patients during dental X-ray examinations

Tabela 2. Wejściowe dawki powierzchniowe (ESD) otrzymywane przez pacjentów w trakcie stomatologicznych badań rentgenowskich

\begin{tabular}{|c|c|c|c|c|}
\hline \multirow{2}{*}{$\begin{array}{c}\text { Examination } \\
\text { Procedura medyczna }\end{array}$} & \multicolumn{4}{|c|}{$\begin{array}{c}\text { ESD } \\
\text { Dawka ESD } \\
{[\mu \mathrm{Gy}]}\end{array}$} \\
\hline & $\mathrm{R}$ & $\mathrm{M}$ & $\mathrm{R}$ & M \\
\hline Dental radiographs: fore-tooth / Radiografia zęba: siekacz & $63.0-1833.0$ & 592.2 & $102.4-2942.0$ & 1036.5 \\
\hline Dental radiographs: premolar / Radiografia zęba: ząb przedtrzonowy & $102.4-2430.0$ & 840.7 & - & - \\
\hline Dental radiographs: molar / Radiografia zęba: zab trzonowy & - & - & $159.5-6113.0$ & 1520.3 \\
\hline
\end{tabular}

Abbreviations as in Table 1 .

impact on the quality of the obtained X-ray image but also on the dose the patient receives during the examination. Incompatibility of the exposure time set to the actual value leads to an increase of the received dose if the test is too long and directly affects the quality of the $\mathrm{X}$-ray image (the image is not very clear due to the high density of the film). Too short exposure time may lead to a necessity to repeat the test and, as a consequence, to re-exposure the patient to ionizing radiation.

Moreover, long-term or improper use of the X-ray tube causes the expansion of the focal spot size and, thus, affects the contrast and resolution of the X-ray image. This results in low quality of the X-ray image which makes the correct diagnosis and medical treatment even more difficult. On the other hand, it is observed that the condition of X-ray units has been systematically improved. This is achieved mainly due to the replacement of the old equipment with modern designs. The continuous replacement of X-ray units improves the quality of X-ray images.

The method of image recording has also changed. Dental medical centers resign from the use of analog $\mathrm{X}$-ray film to the advantage of digital recording. This is also a positive change for patients, as correct performing examinations with digital recording should result in a dose which is about two times lower than in the case of procedures where the analog X-ray film is used $(13,14)$. The reduction in doses results from lower set-up exposure conditions, in particular its duration. The distribution of the measured doses found in this study cannot be solely attributed to the difference in the anatomy of the patient or the image recording method. It seems that there are other important factors, like the technical condition of the X-ray unit and also the choice of exposure parameters, selected by dentists, such as the current time load (mAs) and the high voltage $(\mathrm{kV})$. It is highly recommended to put the required group of doctors under an obligation to attend regular (every five years) training on radiation protection of patients. The completion of the training should be certified by a national exam. The present study also showed cases where the dose reference level of $5 \mathrm{mGy}$ (2) for dental X-ray imaging was exceeded in 9 cases (1.9\%). This resulted from both X-ray unit malfunction or an inappropriate selection of exposure parameters by the dentist.

Basing on the obtained entrance surface dose (ESD) values received by adults and children, the average effective dose has been estimated considering the appropriate tissue weighting factor (15). For a child, the average effective dose was $1.1 \mu \mathrm{Sv}$ with a range of $0.1-2.4 \mu \mathrm{Sv}$ and for adults $-1.3 \mu \mathrm{Sv}$ with a range of $0.1-6.1 \mu \mathrm{Sv}$. The values obtained do not differ from those estimated in other European countries including the United Kingdom (average: $3 \mu \mathrm{Sv}$ ) and France (average: $5 \mu \mathrm{Sv}$ ) $(4,16)$. Similarly, in Brazil, the highest value is below $5.2 \mu \mathrm{Sv}$ (17).

Taking into account the number of intraoral dental examinations (a total of 1228610 ) conducted in the region of Mazovia (18), it was possible to estimate the annual collective dose to the population of the region of Mazovia (19). The value is $1.579 \mathrm{~Sv} /$ year. The estimated collective dose which comes only from the medical use of ionizing radiation in intraoral dental diagnosis has little contribution to the total collective dose of medical use of ionizing radiation in general medicine. Its value was estimated at the level of 1638.242 Sv/year in the Masovian Province (19). 


\section{CONCLUSIONS}

1. The obtained results confirm the necessity of the quality control of the physical parameters of X-ray units used in Poland, because it allows to detect malfunctions, which consequently may pose a threat to the health or life of the patient.

2. It is essential to constantly monitor the situation regarding the technical condition of X-ray units which affects the size of the population's exposure to ionizing radiation.

3. It seems obligatory to develop standard procedures to optimize the value of the received X-ray doses. Basing on the above, X-ray dental medical centers will be able to prepare their own working procedures.

4. It is vital to raise dentists' awareness on the applicable legal regulations and the effects of X-rays on the human body.

\section{REFERENCES}

1. EUR 16260 EN. European guidelines on quality criteria for diagnostic radiology images. European Commission; 1996.

2. [Regulation of Minister of Health form 18th February 2011 on requirements for safe use of ionizing radiation for all types of medical exposure]. Journal of Laws of the Republic of Poland from 2011 no. 51, position 265. Polish.

3. Pruszyński B, editor. [Radiology. Diagnostic imaging]. Warszawa: PZWL; 2008. Polish.

4. Hart D, Wall BF, Hillier MC, Shrimpton PC. Frequency and collective dose for medical and dental X-ray examinations in the UK. Report HPA-CRCE-012; 2010.

5. Berrington de Gonzalez A, Darby S. Risk of cancer from diagnostic X-rays: estimates for the UK and 14 other countries. Lancet. 2004;363:345-51.

6. Bekas M. [Procedure PB-03-LHR/HR. Quality control procedures for the monitoring and testing of dental X-ray units]. Warszawa: NIZP-PZH; 2006. Unpublished. Polish.

7. Pachocki K, Różycki Z. [Condition of diagnostic roentgen apparatus in Poland. Types and year of production]. Pol J Radiol. 1993;57(3-4):65-8. Polish.
8. Różycki Z, Pachocki K. [Quality assurance in diagnostic radiology. Control of the beam limiting device. I. Method]. Pol J Radiol. 1993;57(3-4):172-4. Polish.

9. Różycki Z, Pachocki K. [Quality assurance in diagnostic radiology. Control of the beam limiting device. II. Investigation and results]. Pol J Radiol. 1993;57(3-4):175-8. Polish.

10. Fabiszewska E, Pachocki K, Tołwiński J. [Quantitative and qualitative evaluation of mammographic units in Poland]. Pol J Radiol. 1997;62(1):38-41. Polish.

11. Bekas M, Pachocki KA, Różycki Z, Wieprzowski K, Fabiszewska E. [Evaluation of mammographic units in Poland in the view of current requirements of radiation protection regulations]. Rocz Panstw Zakl Hig. 2006;57(1):81-90. Polish.

12. Hellwig Z. [Elements of probability and mathematical statistics]. Warszawa: PWN; 1995. Polish.

13. Manousaridis G, Koukorava C, Hourdakis CJ, Kamenopoulou V, Yakoumakis E, Tsiklakis K. Establishment of diagnostic reference levels for dental intraoral radiography. Radiat Prot Dosim. 2013;156(4):455-7, http://dx.doi.org/10.1093/rpd/nct100.

14. Lambrecht JT, Roth J, Kiefer HP. Dose exposition from intra- and extraoral dental radiography. Int Congr Ser. 2004;1268:1147-51.

15. ICRP Publication 60. 1990 Recommendations of the International Commission on Radiological Protection. Ann ICRP. 1991;21(1-3).

16. Scnaff P, Donadieu J, Pirard P, Aubert B. Population exposure to ionizing radiation from medical examination in France. Br J Radiol. 2008;81(963):204-13, http://dx.doi.org/10.1259/bjr/24344062.

17. Garcia Silva MA, Wolf U, Heinicke F, Gründler K, Visser $\mathrm{H}$, Hirsch E. Effective dosages for recording Veraviewepocs dental panoramic images: analog film, digital and panoramic scout for CBCT. Oral Surg Oral Med Oral Pathol Oral Radiol Endod. 2008;106(4):571-7, http://dx.doi.org/10.1016/j.tripleo.2008.03.031.

18. Bekas M, Gajewski AK, Pachocki A. How often are $\mathrm{X}$-rays used as diagnostic tool by healthcare providers in the Mazovian province of Poland. Rocz Panstw Zakl Hig. 2013;64(2):155-60.

19. Bekas M. [Radiation risk from X-ray diagnostic procedures and cancer risk in the Mazovian district] [dissertation]. Warszawa: NIZP-PZH; 2011. Polish.

Ten utwór jest dostępny na licencji Creative Commons Uznanie autorstwa - Użycie niekomercyjne 3.0 Polska / This work is licensed under a Creative Commons Attribution-NonCommercial 3.0 Poland License - http://creativecommons.org/licenses/by-nc/3.0/pl/. 